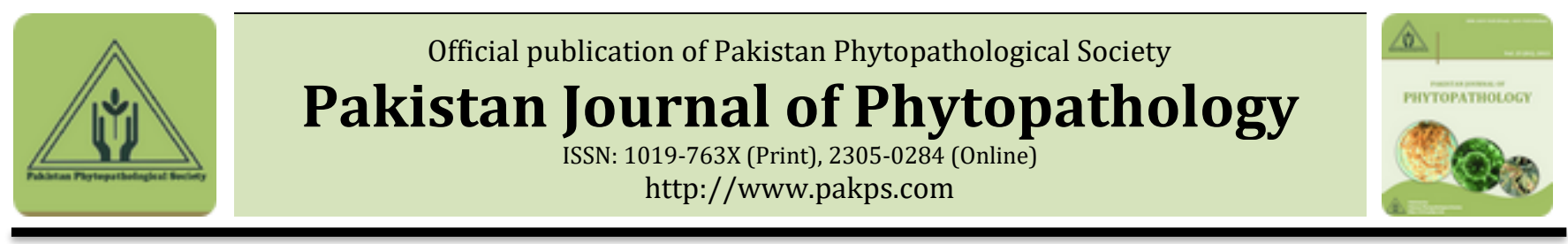

\title{
OPTIMIZATION OF ENVIRONMENTAL FACTORS CONDUCIVE FOR STRIPE RUST OF WHEAT
}

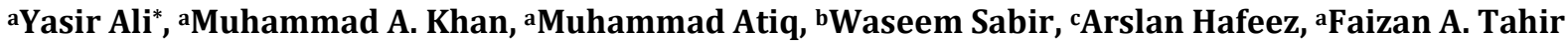 \\ ${ }^{a}$ Department of Plant Pathology, University of Agriculture, Faisalabad, Pakistan. \\ ${ }^{b}$ Wheat Research Institute, Ayub Agriculture Research Institute, AARI, Faisalabad, Pakistan. \\ 'Department of Botany, University of Agriculture Faisalabad, Pakistan.
}

\begin{abstract}
A B S T R A C T
Wheat rusts are the significant diseases of wheat crop and potential threats worldwide. Among all major wheat diseases occurring in all wheat growing areas of the world, yellow rust caused by Puccinia striiformis f. sp. tritici is a big hazard when it occurs in severe condition. The susceptible germplasm and conducive environmental conditions contribute towards wide outbreak of rust diseases. In the present study, eight wheat lines were screened out and correlated with epidemiological factors (temperature, relative humidity, rainfall and wind speed). Results showed that maximum disease severity was observed at minimum and maximum temperature ranging from 13.7-16.7 and $23.5-27.65{ }^{\circ} \mathrm{C}$ respectively. Their disease severity was increased with increase in relative humidity ranging from $52-$ $64 \%$. Similarly, rain fall ranging from $5.7-21.99 \mathrm{~mm}$ and wind speed $6.88-11.73 \mathrm{~km} / \mathrm{h}$ respectively proved conducive for yellow rust development in Sargodha. A positive correlation was observed between disease severity and all environmental factors.
\end{abstract}

Keywords: Characterization, environmental factors, stripe rust, wheat.

\section{INTRODUCTION}

Wheat (Triticum aestivum L.) is widely growing cereal crop of the world. It is major source of nutritional die. It contains carbohydrates, iron and vitamins like riboflavin, niacin, thiamine and gluten (Botella-Pavia, and Rodriguez. 2006). It is cultivated annually on more 240 million hectares throughout the world with six hundred million tons production while in Pakistan it is grown on an area of 8.8 million hectare with 25.09 million tons annual production, contributing twenty one percent to GDP (FAO, 2011).

Wheat production is influenced by many biotic and abiotic factors which causes reduction in its produce. Among biotic problems, rusts, smuts, bunts, and aphids are important. The salient abiotic factors are

Submitted: September, 23, 2017

Revised: December, 11, 2017

Accepted for Publication: December 20, 2017

* Corresponding Author:

Email: yasirklasra.uca@gmail.com

(C) 2017 Pak. J. Phytopathol. All rights reserved. excessive heat, drought, salinity, winds, hail storms, fogs and excessive cloudy weather during growth and ripening seasons (Hussain et al., 2004). Among all rust diseases stripe rust caused by Puccinia striiformis, is a potential threat to successful wheat production (Hussain et al., 2006). Puccinia striiformis appears as yellow uredia (spore mass) on the surface of leaf in the form of stripes or lines but also rarely present on the leaf sheath, stem sand head. Black spores (telia) are produced in stripes as the crop mature and these black spores are enclosed by the leaf outer surface known as epidermis (Smiley, and Cynthia. 2003).

Stripe rust of wheat causes a wide range of yield losses ranged from 10-70\% depending upon the varieties and disease severity development with respect to environmental conditions (Chen, 2005). Environmental conditions play an important role in driving the pathogen-host interaction. Yellow rust epidemic depends upon climatic factors such as rainfall, relative humidity and temperature (Emge, 1975). P. striiformis survives as resting mycelium in 
winter. In the spring fungus grow and produces vigorous sporulating lesions in the cool moist weather. It expressed maximum infection at $30-35{ }^{\circ} \mathrm{C}$ (max. temperature), $15-16{ }^{\circ} \mathrm{C}$ (mini. temperature) with more than $70 \%$ relative humidity (Khan et al., 2006). Environmental conditions of Pakistan are changing continuously every year which is the main cause of emergence of new lethal strains of $P$. striiformis. Therefore, the present study was conducted to observe the impact of temperature, relative humidity, rainfall and wind speed on the development of yellow rust of wheat.

\section{MATERIALS AND METHODS}

Establishment of disease screening nursery: Wheat seeds of eight lines viz., A-24, A-20, K-11, A-09, A-17, A$08, A-25$ and A-29 were sown in the experimental area of Plant Pathology, University college of Agriculture, University of Sargodha, on November 21, 2013. Each test entry was sown in eight plots following three replications with RCBD. Line sowing was done as; plot size $=1219.2 \mathrm{~cm}$, space between two plots $=152.4 \mathrm{~cm}$, space between two rows $=304.8 \mathrm{~cm}$.

Along with each line, a line of highly susceptible wheat rust spreader i.e. Morocco was sown for creating the yellow rust epidemic. No fungicides were sprayed to keep the crop under maximum disease severity conditions. In order to maintain crop vigor normal agronomic practices including recommended fertilization dose and irrigation schedule were applied. During the growing season, the nursery was inoculated by the urediniospore suspension of rust through rubbing and spraying and hypodermal injection methods to create rust disease epidemic (Roelf et al., 1992).

Recording of Rust Severity: Yellow rust disease severity and response of varieties were recorded by the modified Cobb,s scale (Peterson et al., 1949). At the initiation of disease on different varieties, rating was taken. Disease severity on different genotypes was kept recording up to crop maturity. The final disease rating near maturity was taken when spreader became highly susceptible.

Relationship of environmental conditions conducive for yellow rust development: Data of environmental conditions i.e. wind speed, minimum and maximum temperatures, rainfall and relative humidity was collected from Agro-metrology observatory, University college of Agriculture, University of Sargodha. The relationship between environmental conditions and disease severity was determined through correlation analysis using statistical software. Environmental data served as independent variable while disease severity was used as dependent variable. Environmental parameters having significant influence on yellow rust development was studied in detailed by plotting the data graphically. During current research, Minitab 15 by Minitab Inc. U.S.A. was used.

Statistical analysis: The environmental data and disease severity data were subjected to correlation and regression analysis to determine the relationship of environment with the disease severity. Data of stripe rust severity recorded on varieties/lines were processed for AUDPC using CIMMYT AUDPC calculating table.

\section{RESULTS}

Screening of wheat germplasm against stripe rust: Final response of wheat genotypes/lines showed that four lines A-09, A-17, A-08 and A-29 were susceptible against stripe rust of wheat with area under stripe rust progress curve (AUYRPC) value 898.21, 979.86, 950.25 and 1027.25 , respectively and the remaining four lines A-24, A-20, K-11 and A-25 were moderately susceptible with AUYRPC value 856.28, 845.64, 895.3 and 857.33 respectively. No line/genotype showed resistant, moderately resistant or immune response to stripe rust of wheat (Table 1).

Table 1. Response of different lines against stripe rust of wheat on the basis of AUYRPC value during year 2014

\begin{tabular}{llllllll}
\hline Sr \# & Lines & $18-03-2014$ & $25-03-2014$ & $1-04-2014$ & $8-04-2014$ & AUYRPC value & Reaction \\
\hline 1 & A-24 & 6.65 & 31.65 & 60 & 55 & 856.28 & MS \\
2 & A-20 & 5 & 28.33 & 61.65 & 56.65 & 845.64 & MS \\
3 & K-11 & 7.5 & 31.65 & 65 & 55 & 895.3 & MS \\
4 & A-09 & 10 & 25 & 66.65 & 63.33 & 898.21 & S \\
5 & A-17 & 5 & 38.33 & 66.65 & 65 & 979.86 & S \\
6 & A-08 & 11.5 & 30 & 65 & 70 & 950.25 & S \\
7 & A-25 & 6.65 & 31.65 & 60 & 55 & 857.33 & MS \\
8 & A-29 & 8.5 & 40 & 70 & 65 & 1027.25 & S \\
\hline
\end{tabular}


Correlation of environmental factors with stripe rust: All environmental factors i.e. maximum and minimum air temperature, relative humidity, rainfall and wind speed had significant $(\mathrm{P}<0.05)$ and highly significant correlation $(\mathrm{P}<0.01)$ with stripe rust of wheat on all eight varieties.
The correlation of maximum temperature with stripe rust was found statistically highly significant, while minimum air temperature, relative humidity, rainfall and wind speed showed statistically significant correlation to all varieties (Table 2).

Table 2. Correlation of environmental factors with disease severity of stripe rust during year 2014 in Sargodha

\begin{tabular}{|c|c|c|c|c|c|c|}
\hline Sr. No. & Lines & $\begin{array}{l}\text { Max. Temp } \\
\left({ }^{\circ} \mathrm{C}\right) .\end{array}$ & $\begin{array}{l}\text { Min. Temp } \\
\left({ }^{\circ} \mathrm{C}\right)\end{array}$ & R.H (\%) & Rainfall (mm) & Wind speed $(\mathrm{km} / \mathrm{h})$ \\
\hline 1 & A-24 & $\begin{array}{l}0.725^{* *} \\
0.008\end{array}$ & $\begin{array}{l}0.860^{* *} \\
0.000\end{array}$ & $\begin{array}{l}0.700^{*} \\
0.011\end{array}$ & $\begin{array}{l}0.945^{* *} \\
0.000\end{array}$ & $\begin{array}{l}0.645^{*} \\
0.023\end{array}$ \\
\hline 2 & A-20 & $\begin{array}{l}0.560 \\
0.058\end{array}$ & $\begin{array}{l}0.962^{* *} \\
0.000\end{array}$ & $\begin{array}{l}0.507 \\
0.092\end{array}$ & $\begin{array}{l}0.925^{* *} \\
0.000\end{array}$ & $\begin{array}{l}0.641^{*} \\
0.025\end{array}$ \\
\hline 3 & $\mathrm{~K}-11$ & $\begin{array}{l}0.792^{* *} \\
0.002\end{array}$ & $\begin{array}{l}0.770^{* *} \\
0.003\end{array}$ & $\begin{array}{l}0.776^{* *} \\
0.003\end{array}$ & $\begin{array}{l}0.930^{* *} \\
0.000\end{array}$ & $\begin{array}{l}0.668^{*} \\
0.018\end{array}$ \\
\hline 4 & A-09 & $\begin{array}{l}0.789^{* *} \\
0.002\end{array}$ & $\begin{array}{l}0.829^{* *} \\
0.001\end{array}$ & $\begin{array}{l}0.757^{* *} \\
0.004\end{array}$ & $\begin{array}{l}0.977^{* *} \\
0.000\end{array}$ & $\begin{array}{l}0.740^{* *} \\
0.006\end{array}$ \\
\hline 5 & A-17 & $\begin{array}{l}0.761^{\text {** }} \\
0.004\end{array}$ & $\begin{array}{l}0.844^{* *} \\
0.001\end{array}$ & $\begin{array}{l}0.720^{* *} \\
0.008\end{array}$ & $\begin{array}{l}0.979^{* *} \\
0.000\end{array}$ & $\begin{array}{l}0.768^{* *} \\
0.004\end{array}$ \\
\hline 6 & A-08 & $\begin{array}{l}0.618^{*} \\
0.032\end{array}$ & $\begin{array}{l}0.923^{* *} \\
0.000\end{array}$ & $\begin{array}{l}0.560 \\
0.058\end{array}$ & $\begin{array}{l}0.949 * * \\
0.000\end{array}$ & $\begin{array}{l}0.726^{* *} \\
0.007\end{array}$ \\
\hline 7 & $A-25$ & $\begin{array}{l}0.710^{*} \\
0.010\end{array}$ & $\begin{array}{l}0.866^{* *} \\
0.000\end{array}$ & $\begin{array}{l}0.685^{*} \\
0.014\end{array}$ & $\begin{array}{l}0.939 * * \\
0.000\end{array}$ & $\begin{array}{l}0.634^{*} \\
0.027\end{array}$ \\
\hline 8 & A-29 & $\begin{array}{l}0.583^{*} \\
0.047\end{array}$ & $\begin{array}{l}0.933^{* *} \\
0.000\end{array}$ & $\begin{array}{l}0.551 \\
0.063\end{array}$ & $\begin{array}{l}0.899^{* *} \\
0.000\end{array}$ & $\begin{array}{l}0.550 \\
0.064\end{array}$ \\
\hline
\end{tabular}

Upper values indicating Pearson's correlation coefficient; Lower values indicating level of significance at $5 \%$ probability ; * Significant $(P<0.05) ;{ }^{* *}=$ highly significant $(P<0.01)$

The correlation of maximum temperature with $\%$ disease severity of rust was positive within the lines A-29, A-08, A-17 and A-09. With one unit increase in maximum temperature from 23.5 to $27.65{ }^{\circ} \mathrm{C}$ yellow rust severity increased gradually. The lines showed highest disease severity when maximum temperature increased from 26.5 to $27.65{ }^{\circ} \mathrm{C}$. The relationship was best explained by linear regression models as indicated by $0.76,0.62,0.71$ and $0.58 \mathrm{r}$ values respectively (Figure 1).

Linear regression models best explained the positive correlation between \% disease severity and minimum temperature as indicated by $0.86,0.96$, 0.77 and $0.83 \mathrm{r}$ values, respectively. The yellow rust disease severity was highest when minimum temperature increased from 16 to $16.7^{\circ} \mathrm{C}$ (Figure 2). A positive correlation was observed between relative humidity and \% disease severity of yellow rust and it was best explained by the linear regression models by as indicated by $0.70,0.51,0.78$ and $0.76 \mathrm{r}$ values respectively. With increase in relative humidity from 52 to $64 \%$ yellow rust severity also increased gradually. Yellow rust disease severity was highest when relative humidity increased from 60 to $64 \%$ (Figure 3).

Different lines responded differently to rainfall and wind speed. The relationship of rainfall and wind speed with \% disease severity was also positive. With increase in rainfall and wind speed from 5.7 $21.99 \mathrm{~mm}, 6.88-11.73 \mathrm{~km} / \mathrm{h}$, respectively, yellow rust severity also increased gradually. The lines showed highest disease severity when rainfall and wind speed increased from 21-21.99 mm, 10-11.73 $\mathrm{km} / \mathrm{h}$ respectively. The relationship was best explained by linear regression models as indicated in Figure 4 \& 5 respectively. 


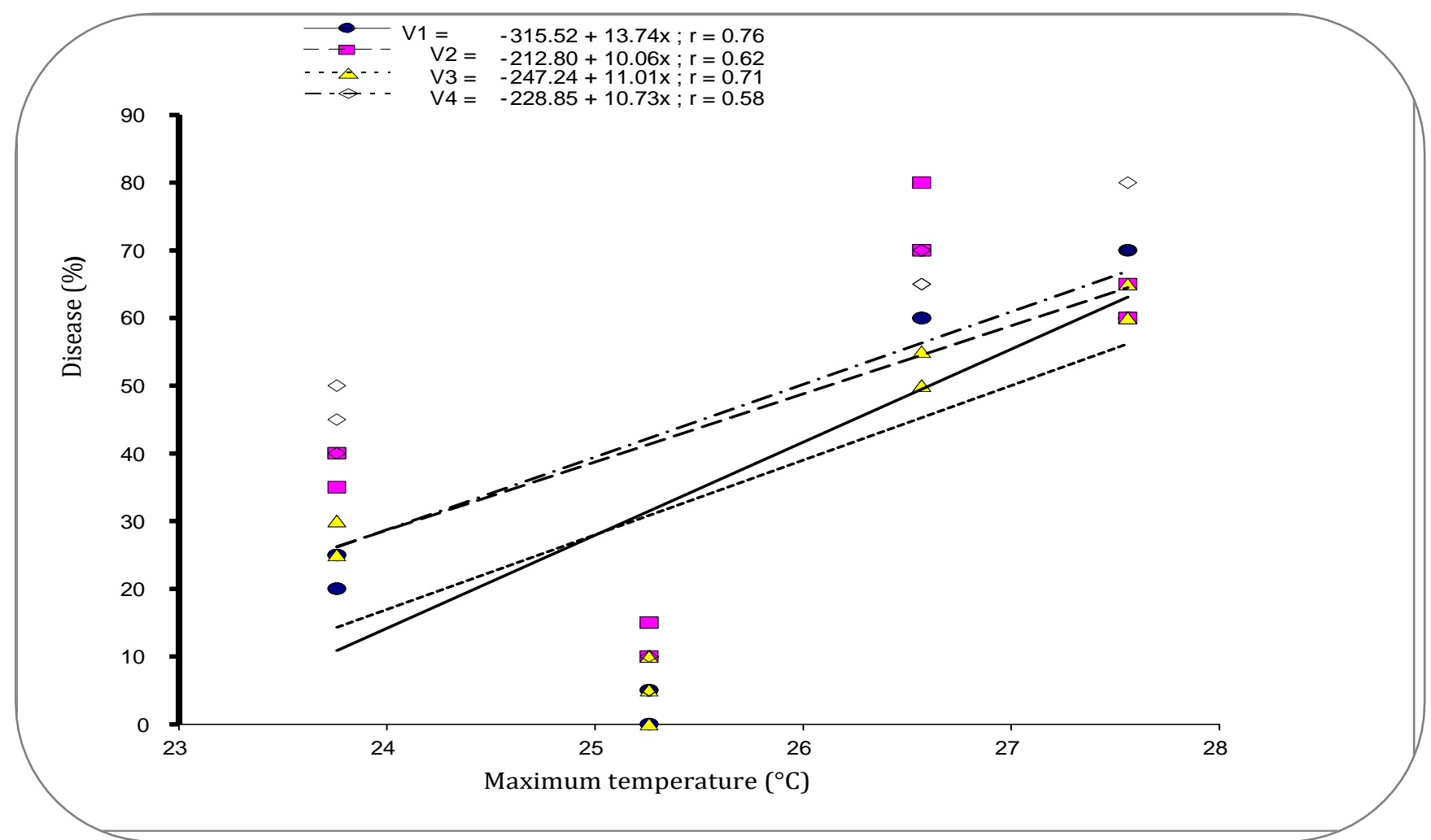

Figure 1. Relationship of maximum temperature with yellow rust severity recorded on A-29 (V1), A-08 (V2), A-17

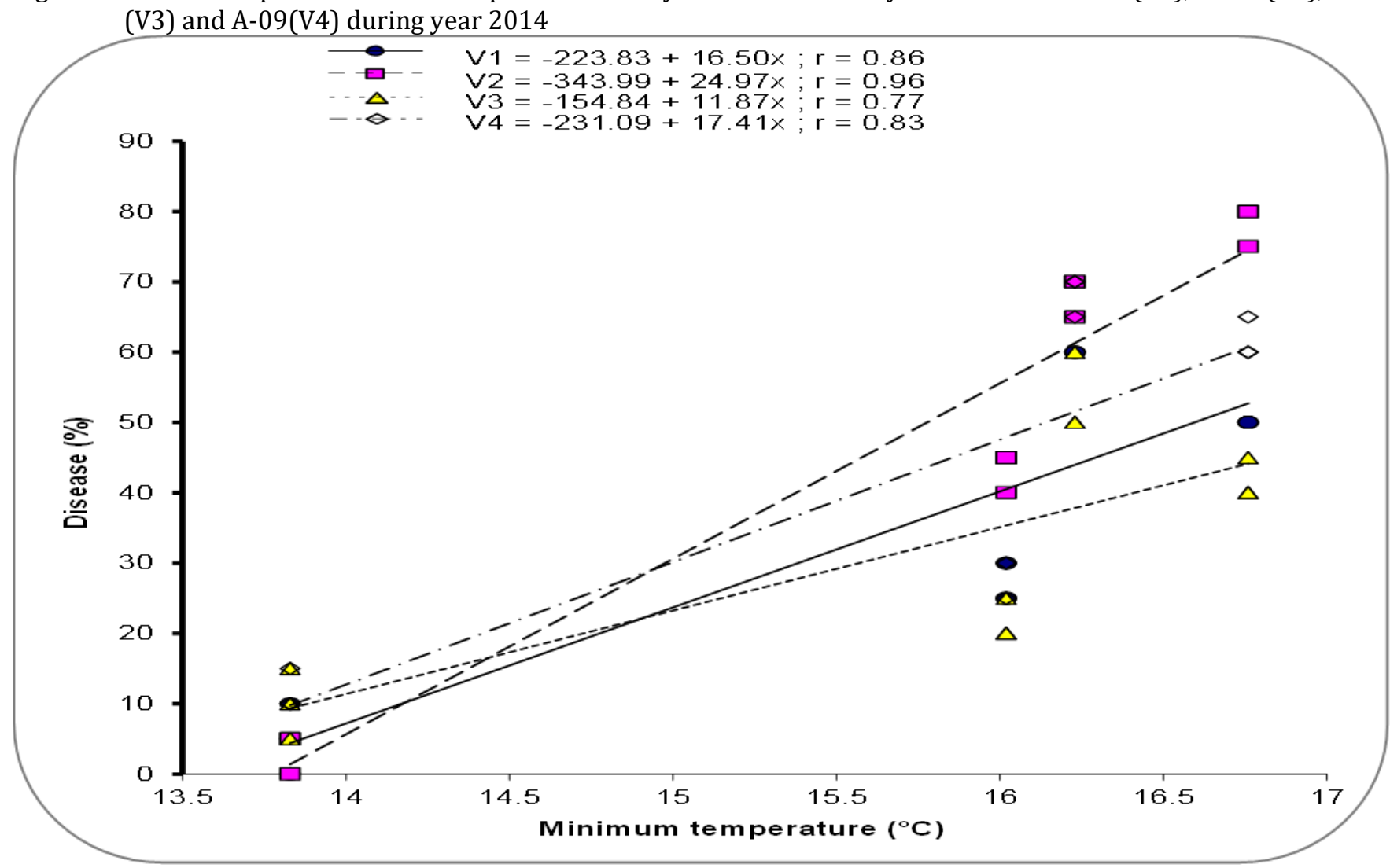

Figure 2. Relationship of minimum temperature with yellow rust severity recorded on A-29 (V1), A-08 (V2), A-17 (V3) and A-09(V4) during year 2014 


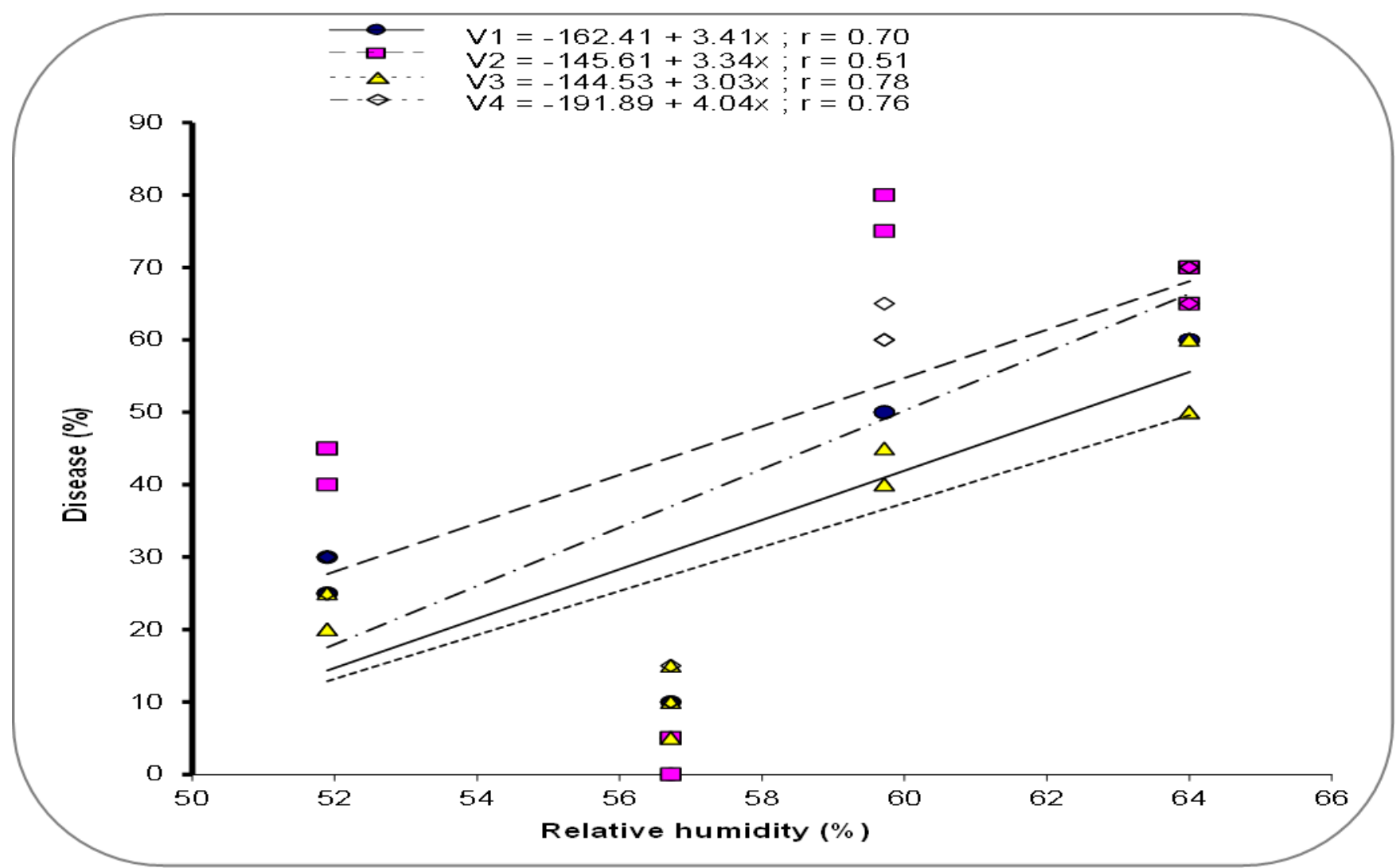

Figure 3. Relationship of relative humidity with yellow rust severity recorded on A-29 (V1), A-08 (V2), A-17 (V3) and A-09(V4) during year 2014

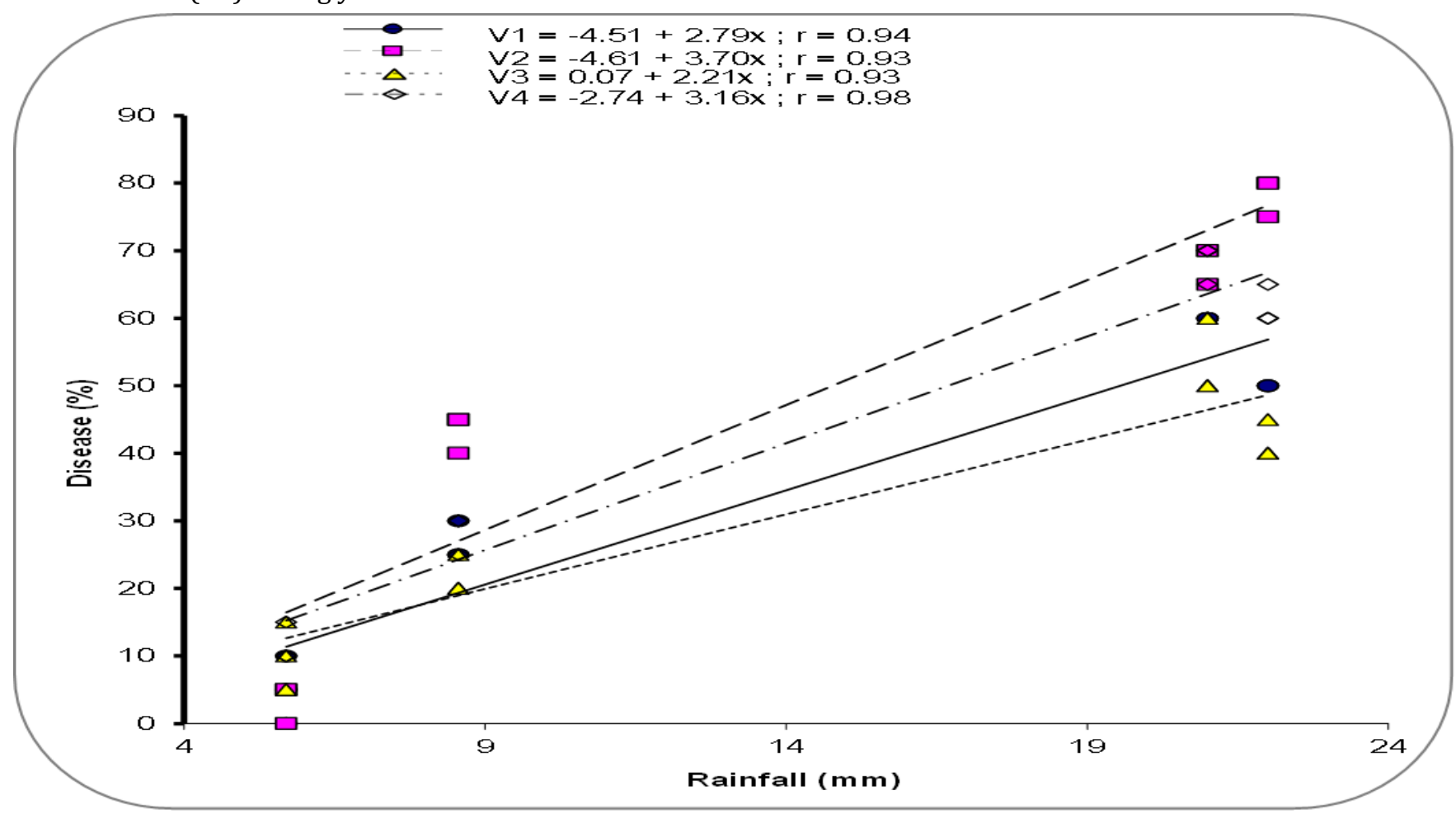

Figure 4. Relationship of rainfall with yellow rust severity recorded on A-29 (V1), A-08 (V2), A-17 (V3) and A-09(V4) during year 2014 


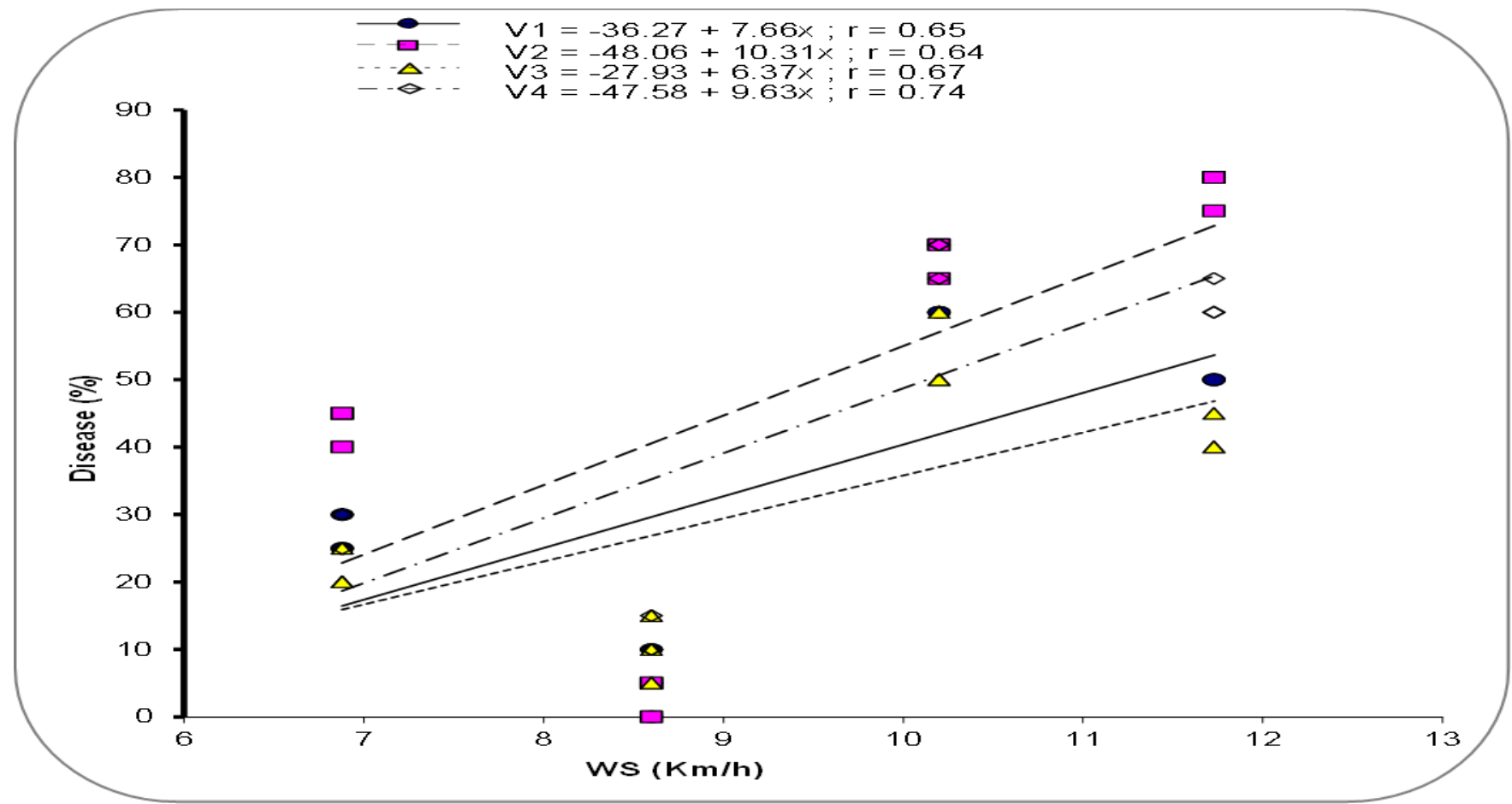

Figure 5. Relationship of wind speed with yellow rust severity recorded on A-29 (V1), A-08 (V2), A-17 (V3) and A09(V4) during year 2014

\section{DISCUSSION}

In the present work the correlation of environmental factors including maximum temperature, minimum temperature, relative humidity, rain fall and wind speed with yellow rust disease severity was examined. The results showed that all environmental factors had significant correlation with disease severity. With one unit increase in minimum and maximum temperature, relative humidity, rainfall and wind speed disease severity also increased. P. striiformis both at low (10-18 ${ }^{\circ} \mathrm{C}$ ) and high $\left(12-28{ }^{\circ} \mathrm{C}\right)$ temperature establish for latent period, lesion length, lesion width, lesion area, and spore production on adult plants. At minimum temperature the intensity of pustules per unit area of infected leaves increase rapidly during temperature $7-15{ }^{\circ} \mathrm{C}$, fungus sporulated and produced more spores of lesion per day (Milus et al., 2009). During high temperature, fungus sporulated, grew $0.2 \mathrm{~mm}$ faster, $1.2 \mathrm{~mm}$ wider and produced more spores per inoculation site per day. At $21.4{ }^{\circ} \mathrm{C}$ temperature isolates extent within the leaf at proportion of $8.9 \mathrm{~mm}$ per day. Lesions increase in extent as veins check their lateral extension. The rate of expansion is linear and decrease with growth of the host (Emge, 1975).

Reuiring a relative humidity nearby to wetness uredinospores develop in free water, which results in the formation of condensation droplets around which the germ tubes grow. The condensation must last at least three hour before germination begins. This increase the rate of spore germination which will definitely stop if a period of dryness occur. In the presence of humidity, appressoria germination increased between $4-25{ }^{\circ} \mathrm{C}$ temperatures by $1.2 \%$ for each degree hour exceeding $6.1^{\circ} \mathrm{C}$ (Zadoks, 1972)

Rainfall also plays a vital role in disease development. Raindrops released uredinospores either by direct impact or by splashing with rains of 5 to $10 \mathrm{~mm}$ per hour and sori are emptied within about $1 \mathrm{hr}$. This delay depends on how rapidly the sori are emptied and therefore on the intensity of the rain. Dispersion by rain, however imperfect in distance, can be very effective because the units of dispersal, spore clusters, by rain have a very high germination prospective (Rapilly et al., 1970).

The uredinospores dispersal rate increases exponentially with increase in wind speed, and wind blasts thus play a major role in spread of rust. However, results obtained by use of models indicate, that with respect to the canopy roughness, spore transport is nil for speeds under $0.25 \mathrm{~m} / \mathrm{sec}$, whereas spores must be considered as a gas for wind speeds over $2.5 \mathrm{~m} / \mathrm{sec}$ (Rapilly et al., 1970). 
Park et al. (1992) tested the response of 83 Australian wheat cultivars/varieties to yellow rust caused by $P$. striiformis f. sp. tritici at the seedling stage under favorable conditions of low 5-18 ${ }^{\circ} \mathrm{C}$ temperature and high $15-24{ }^{\circ} \mathrm{C}$ temperature. Singh and Tewari (2001) studied the effect of environmental factors in the development of yellow and leaf rusts of wheat. High severity of yellow rust was favored by minimum temperature $\left(10.9{ }^{\circ} \mathrm{C}\right)$ and maximum temperature $(25.7$ ${ }^{0} \mathrm{C}$ ), rainfall $44.6 \mathrm{~mm}, 2.0$ rainy days per week and relative humidity 49.6-88.1\%. Geagea et al. (2000) stated that spores of Puccinia striiformis and Puccinia recondita f.sp. tritici were mainly spread by wind. The experimental results, by using a rain simulator having drop size $4.9 \mathrm{~mm}$, rain effects on spread of stripe and brown or leaf rust were reported. Similarly results of this study showed that minimum and maximum temperature, relative humidity rainfall and wind speed play a significant role in the development of yellow rust of wheat.

\section{REFERENCES}

Botella-Pavía, P. and M. Rodríguez-Concepción. 2006. Carotenoid biotechnology in plants for nutritionally improved foods. Physiologia Plantarum, 126: 369-381.

Chen, X. M. 2005. Epidemiology and control of stripe rust [Puccinia striiformisf. sp.tritici] on wheat. Canadian Journal of Plant Pathology, 27: 314-337.

Emge, R. G. 1975. Growth of the Sporulating Zone of Puccinia striiformis and Its Relationship to Stripe Rust Epiphytology. Phytopathology, 65: 679.

FAO. 2011. Perspectives agricoles de l'OCDE et de la FAO. Éditions OCDE.

Geagea, L., L. Huber, I. Sache, D. Flura, H. A. McCartney and B. D. L. Fitt. 2000. Influence of simulated rain on dispersal of rust spores from infected wheat seedlings. Agricultural and Forest Meteorology, 101: 53-66.

Hussain, M., M. A. Khan, S. Kirmani and Ehsan-ul-Haque. 2004. Pathotypes and man guided evolution of Puccinia striiformis West and sp tritici in Pakistan. Page 21, In: Abstracts, Second Regional Yellow
Rust Conference for Central \& West Asia and North Africa, 22-26 March 2004, Islamabad, Pakistan.

Hussain, M., N. Ayub, S. Khan, M. Khan, F. Muhammad and N. Ahmad. 2006. Pyramiding rust resistance and high yield in bread wheat. Pakistan Journal of Phytopathology (Pakistan).

Khan, M., M. Hussain and M. Sajjid. 2006. A two environmental variable model to predict wheat leaf rust based on 10 years data. Pakistan Journal of Phytopathology (Pakistan).

Milus, E. A., K. Kristensen and M. S. Hovmøller. 2009. Evidence for Increased Aggressiveness in a Recent Widespread Strain of Puccinia striiformisf. sp.tritici Causing Stripe Rust of Wheat. Phytopathology, 99: 89-94.

Park, R. F., G. J. Ash and R. G. Rees. 1992. Effects of temperature on the response of some Australian wheat cultivars to Puccinia striiformis f. sp. tritici. Mycological Research, 96: 166-170.

Peterson, R. F., A. B. Campbell and A. E. Hannah. 1948. A Diagrammatic Scale for Estimating Rust Intensity on Leaves and Stems of Cereals. Canadian Journal of Research, 26: 496-500.

Rapilly, F., J. Fournet and M. Skajennikoff. 1970. Etudes sur l'epidemiologie et la biologie de la rouille jaune du ble Puccinia striiformis Westend. Annales de phytopathologie.

Roelf, A. P., R. P. Singh, and E. E. Sari. 1992. Rust diseases of wheat: Concept and methods of disease management 'Mexico' D.F. CIMMYT. pp. 81.

Singh, T. and A. Tewari. 2001. Role of weather conditions in the development of foliar diseases of wheat under tarai conditions of north-western India. Plant Disease Research-Ludhiana-, 16: 173-178.

Smiley, R. and M. Cynthia. 2003. Information on wheatstripe rust (yellow rust), an online guide to Plant Disease Control, Oregon State University Extension.

Zadoks, J. (1972). "Methodology of epidemiological research." Annual Review of Phytopathology 10(1): 253-276. 